\title{
ROLE OF THE VIRGIN MARY AT THE SIEGE OF CONSTANTINOPLE IN $626^{*}$
}

According to an eyewitness, in the battle for Constantinople in August 626 the Virgin Mary "put flight with a single blow the military force of both enemies", ${ }^{1}$ namely, Khagan, the king of Avars, and his Persian ally. The miracle of the Theotokos is the main point of the homily that was delivered after the liberation of the Constantinopolitans from the terror, caused by the siege and attacks by the troops tenfold superior in force. Bearing in mind, what Norman Baynes emphasized, ${ }^{2}$ I will, neglecting the problem of how to understand Mary's power, concentrate on her role as it is described in the text to be quoted. This approach offers by itself, for the the aim of the paper is to show that the famous prooemium of the Akathistos Hymn, Tĩ vं $\pi \varepsilon \rho \mu \alpha \alpha \chi \omega$ $\sigma \tau \varrho \alpha \tau \eta \gamma \tilde{\omega},{ }^{3}$ is a product of "the ten days when the defenders of the

* This article is written in the framework of the project, "Origins of the Byzantine Cult of Mary", financed by the Austrian Science Fund (FWF), No. P20242-G02.

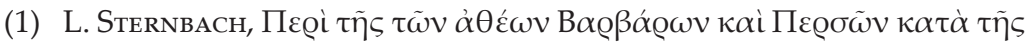

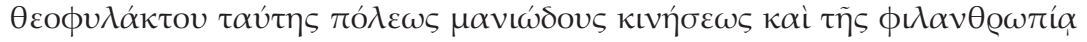

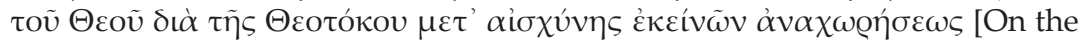
foolish attack of the godless barbars and Persians against this city, protected by God, and of their shameful retreat which the divine love brought about for mankind by the intervention of the Theotokos], in: IDEM (ed.), Analecta

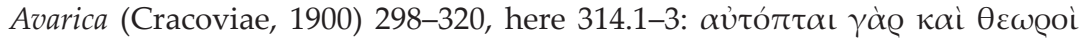

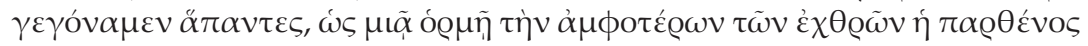

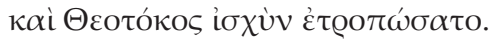

(2) "Modern writers on East Rome, convinced that 'miracles do not happen', have quite banished miracles from their histories and have thereby falsified the picture, for there can be no doubt that the Byzantine lived in a world where miracle could happen and did happen, and that belief in miracle is itself a fact of history which the student ignores at his peril", N. H. BAYNES, The Supernatural Defenders of Constantinople, in: IDEM, Byzantine Studies and Other Essays (London, 1955, repr. 1960) 248-260, here 248.

(3) That is the second prooemium in the edition by C. A. TrYpanis, The Akathistos Hymn, in: IDEM, Fourteen Early Byzantine Cantica (Wien, 1968) 
city withstood all that was thrown against them" - as it is called today - "in the last great war of antiquity". ${ }^{4}$ The question of the original context, which the prooemium refers to, has long been an issue in research on the Akathistos Hymn. ${ }^{5}$ The homily, which will be examined

(Wiener Byzantinistische Studien, 5) 17-39. On the significance of the Tñ

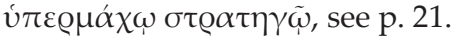

(4) J. D. Howard-Johnston, The siege of Constantinople in 626, in: C. Mango, G. Dagron (eds.), Constantinople and its Hinterland (Aldershot, 1995) (Society for the Promotion of Byzantine Studies, 3) 131-142, here 131. This article considers, in the first place, the position of the defenders. From the Avars' point of view, see W. PoHL, Die Awaren. Ein Steppenvolk in Mitteleuropa 567-822 n. Chr. (München, 22002) 248-255. Best approach to the whole period is provided by the study of W. E. KaEgI, Heraclius. Emperor of Byzantium (Cambridge, 2003). Besides the homily, there are two other eyewitness documents on the siege in 626, a chronicle and a poem. The Chronicon Paschale, composed by an anonymous author, supplies the fullest account of the siege of 626 , in: L. Dindendorfius, Chronicon Paschale (Bonnae, 1832) (Corpus Scriptorum Byzantinae) 716-726; translation in: Michael Wнітву, Mary Wнітву (eds.), Chronicon Paschale 284-628 AD (Liverpool, 1989) (Translated Texts for Historians). The rhetorical poem, called Bellum Avaricum, is one of the six works of George of Pisidia, focussing on the period of Heraclius, in: A. Pertusi, Bellum Avaricum di Giorgio di Pisidia. Poemi, vol. 1. Panegirici Epici (Ettal, 1959) (Studia Patristica et Byzantina, 7) 176-224.

(5) A summary of the opposite viewpoints up to the end of the 1960's is presented by J. L. van Dieten, Geschichte der Patriarchen von Sergios I. bis Johannes VI. (610-715), in: J. L. van Dieten, C. Mango, P. Wirth (eds.), Geschichte der griechischen Patriarchen von Konstantinopel, part 4 (Amsterdam, 1972) (Enzyklopädie der Byzantinistik, 24) 18-21. Obviously from the 1980's onwards Paul Speck's elaborate hypothesis, according to which it was the Patriarch Germanos himself who composed the prooemium, has been under discussion. The reasoning is found in P. SPEсK, Artabasdos, der rechtgläubige Vorkämpfer der göttlichen Lehren (Bonn, 1981) (Poikila Byzantina, 2), 169-171; IDEM, Kaiser Leon III., die Geschichtswerke des Nikephoros und des Theophanes und der Liber Pontificalis. Eine quellenkritische Untersuchung, Teil 1 (Bonn, 2002) (Poikila Byzantina, 19) 295-298. The status questionis seems to be so that, while the majority associates the prooemium with the siege of 626 , the possibility that it could be from the time when Constantinople was saved from the siege by Arabs in 717-718 is still considered, see, e.g., the abstract of the article by M. Hurbanič, The so-called Feast of Akathistos and the tradition of the Avar Siege of Constantinople in 626, in: M. Kulhánková, K. Loudová (eds.), Epea pteroenta. Růženě Dostálové k narozeninám. (Epea pteroenta. Festschrift in Honour of Růžena Dostálová.) (Brno, 2009) 140-141. 
here, is attributed to Theodore Syncellus. ${ }^{6}$ This is the first time when this text is introduced as an evidence of the mutual relationship between the siege of 626 and the Akathistos and its prooemium, though the homily is well known amongst Byzantinists. ${ }^{7}$ The fundamental historical commentary on the homily, day by day, with all parallel sources is given by F. Barišić. ${ }^{8}$ The French translation by Ferenc Makk provides a modest commentary, with the focus on Biblical references. ${ }^{9}$ Paul Speck, in his analysis of the poem Bellum Avaricum by George of Pisidia, refers repeatedly to the homily of Theodore Syncellus, taking also the Akathistos into consideration, ${ }^{10}$ but his remarks confine just to the passages which relate directly to the lines in the poem of George of Pisidia. From this it is clear that the essential part of the homily, the miracle of the Theotokos in Byzantine understanding, would need a thoroughgoing investigation, but this paper is concerned only with

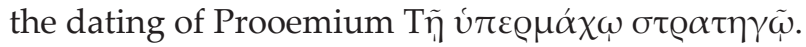

The homily on the siege is rather long, having in printed form a length of 904 lines. The composition is highly rhetorical and extravagantly panegyrical. Distangling all the intertwisted threads and

(6) The extant manuscripts give no author, but the authorship of Theodore Syncellus is considered most likely by modern scholarship. So it is given also in CPG (9736) and BHG (1061): Theodorus Syncellus, De obsidione Constantinopolitana sub Heraclio imperatore. From now on, in this paper the homily is given under Theod. Sync. only. Justification for the authorship to Theodore Syncellus (syncellus or cell-mate of the patriarch) is found in a passage in which the preacher is supposed to be referring to himself (Theod. Sync. 306.23-24), on the attribution of scholars, see S. SzÁdeczKy-Kardoss, Zur Textüberlieferung der „Homilia de obsidione avarica Constantinopolis auctore ut videtur Theodoro Syncello", in: IDEM (ed.), Über die Awarengeschichte und ihre Quellen (Szeged, 1986) (Acta Antiqua et Archaeologica, 24) 173-184, here 299-300.

(7) J. Karayannopulos, G. Weiss, Quellenkunde zur Geschichte von Byzanz (324-1453), Zweite Halbband. (Wiesbaden, 1982) 312.

(8) F. BARIšıč, Le siège de Constantinople par les Avares et les Slaves en 626, Byzantion 24 (1954) 371-395. It is noteworthy that in comparison with all other sources, according to Barisič, the homily of Theodore Syncellus is "le document le plus complet et sans doute le plus pittoresque sur le siège", p. 375.

(9) F. MАKK, Traduction et commentaire de l'homélie écrite probablement par Theodore le Syncelle sur le siège de Constantinople en 626 (Szeged, 1975) (Acta Antiqua et Arhaeologia, 19).

(10) P. Sреск, Zufälliges zum Bellum avaricum des Georgios Pisides (München, 1980) (Miscellanea Byzantina Monacensia, 24). 
strands - typological or allegorical interpretation of the OT prophecies, figures, names and places, dogmatics, numerological consideration and political reflection - all this, related to the recent events, the city of Constantinople and the Eastern Roman Empire would require an extensive research. For our purpose such basic work is not necessary, for in this paper the narrative by Syncellus is examined only in relation to the Akathistos hymn. References to Mary are found throughout the text, altogether more than seventy times, but they are also accumulated around certain themes. Our focus is laid on some of them. Theodore Syncellus uses seven times the word "Mother of God"

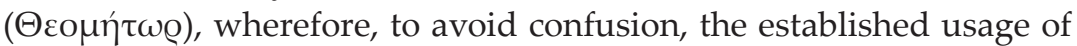
rendering Mother of God for the Theotokos is relinguished here. The word Theotokos shall serve a compromise, instead of the "God-bearer" or "Birthgiver of God".

Following the author's train of thought from beginning to end, we can see that it is first of all the prophet Isaiah who provides the divine perspective for explaining the siege and its outcome. ${ }^{11}$ Thus the point of departure is found in a prophecy of Isaiah: "Get you up to a high mountain, / O herald of good tidings to Zion; / lift up your voice with strength, / O herald of good tidings to Jerusalem. / Lift it up, do not fear; / say to the cities of Judah. / 'Here is your God!' / See, the Lord God comes with might, / and his arm rules for him." 12 This triumphant exclamation "from afar" is now to make evident "the benevolence of God and the Father, regarding the Incarnation and the birth of God the Word from the Theotokos". ${ }^{13}$ That the authors of the homily and the Akathistos present the subject of the Incarnation in the same way is of course significant, ${ }^{14}$ considering the question of an influence. The homilist points out frequently that everything has its origins in

(11) See references to Isaiah, MAKK, Traduction..., 49-59.

(12) Is. 40:9-10, The Holy Bible. New Revised Standard Version. Anglicized Edition (OUP, 1995). This is a reading variant for "O Zion, herald of good tidings" and for "O Jerusalem, herald of good tidings".

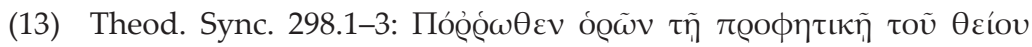

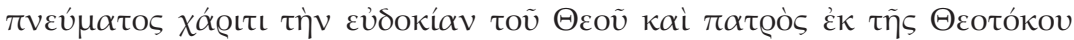

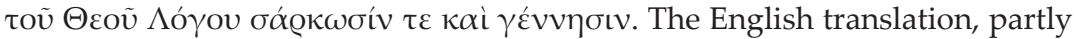
modified, is from www.tertullian.org/fathers by R. Pearse (ed.), Early Church Fathers - Additional Texts (Ipswich, UK, 2007).

(14) On the christology in the Akathistos, see L. M. PeltomaA, The Image of the Virgin Mary in the Akathistos Hymn (Leiden-Boston-Köln, 2001) (The Medieval Mediterranean, 35) 85-101, 203. 
the philanthropy of God, accordingly, also the miracle: "Since there are, here and now, such things to tell which, so to say, by miracle exceeding even the celestial spheres, resulted from the goodness of God towards us, amidst manifold suffering..."15

The miracle how the Incarnation occurred through the Virgin is explained only in the introductory part. The homilist invokes Isaiah, who had "predicted the glory of the only-begotten God and the mystery of the Virgin", to paint for him the current miracle and to assist him to see, as prefigured in the old Jerusalem, all the "miracles and signs that the Theotokos accomplished for this city through the philanthropy of God."16 The sequel makes it clear that the "mystery of the Virgin" is a reference to the prophecy of Isaiah 7:14. This prophecy belongs to a story about king Ahaz. ${ }^{17}$ Thereby Syncellus contrasts the Old Testament king Ahaz, who reigned Jerusalem, with "his" emperor who reigns Constantinople. So, king Ahaz from the house David "did not accept the teaching of the divine mystery of the Virgin, though he was invited by God, by the prophet, to ask that He grant to him a sign on the divine incarnation".$^{18}$ Syncellus does not say it explicitly - but it is evident from the Isaiah passage which he refers to - that in his view the best defence of the city is concerned with firm faith, ${ }^{19}$ undoubt-

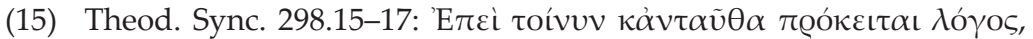

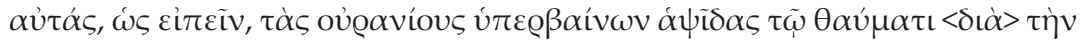

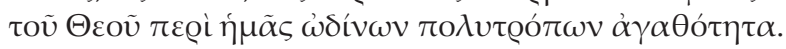

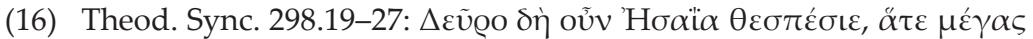

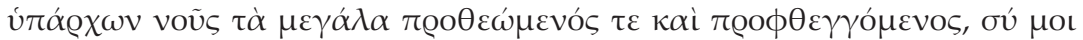

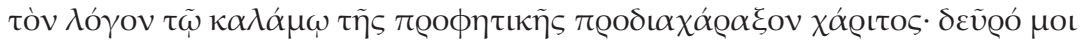

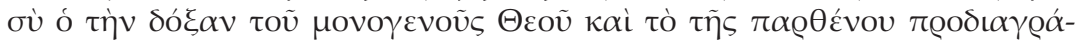

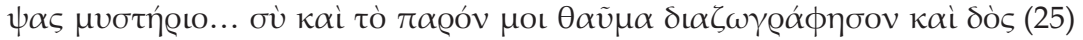

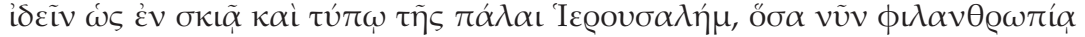

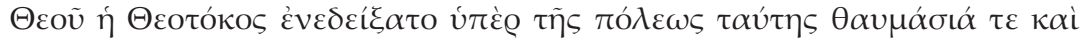
$\tau \dot{\varepsilon} \mathrm{Q} \alpha \tau \alpha$. (TÉ@ $\alpha \varsigma, A$ sign, wonder, marvel, of any appearance or event, in which men believed that they could see the finger of God, and read the future, see LIDDELL-SCOTT.)

(17) Is. 7:3-14.

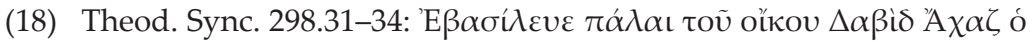

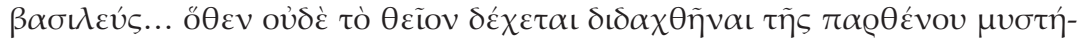

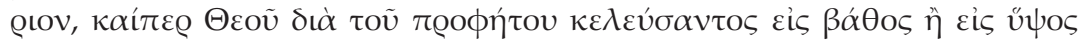

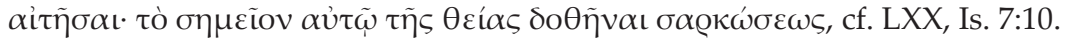

(19) In the story about Ahaz, the Lord says through Isaiah, Is. 7.9: "If you

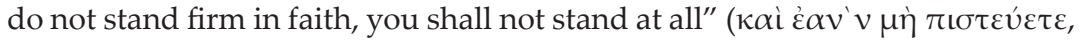

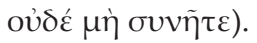


edly in the sense of correct, orthodox, belief. Accordingly, he states that even though Ahaz remained the image of disobedience, the sign was given to the house of David and was fulfilled, "because the Virgin gave birth to God and was preserved virgin". ${ }^{20}$ At the end of the exordium, once more the significance of the Theotokos is affirmed. "All that the prophet said and wrote, a history and parabole, happened to those of the Jews who then lived in Jerusalem, as a figure and example, but was used also as a prediction for us, to whom God spread the grace of his love with the aid of the Theotokos." ${ }^{21}$

The abundancy of numerous comparisons, to inter-relate the Old Testament and present time, do not obscure the homilist's message that the Incarnation signifies victory. So being his juxtaposition of the prophetic words with the Incarnation reflects the early Christian and Byzantine standard view of the Incarnation as victory. In this respect, the Akathistos, forms its own category: it is a hymn on Incarnation, as to its contents, and a hymn on victory, as to its history. ${ }^{22}$ The homily as well as the Akathistos proclaims that the dogma of the Theotokos is prerequisite for victory. They also confess this dogma on the same ground. The sign on the Incarnation, which Syncellus pronounces, is thought to be the Virgin who gave birth to God and was preserved virgin. This evidence differs radically from the sign given by Isaiah: "Look, the virgin is with child and shall bear a son." ${ }^{23}$ Now, it is known that since Nestorian controversy, characteristically in the teaching of Proclus of Constantinople, the virginity of Mary was interpreted as virginity post partum. It was this miracle or mystery that was presented by Proclus as the proof for the divine nature of Christ. ${ }^{24}$ The Akathistos reflects Proclus' thought of the Virgin who remained a virgin as a

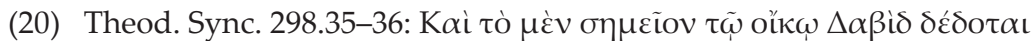

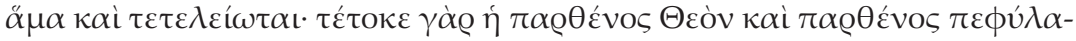
$\kappa \tau \alpha \mathrm{t}$.

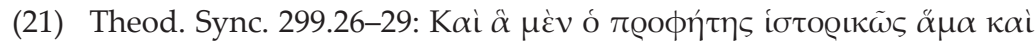

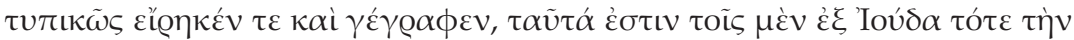

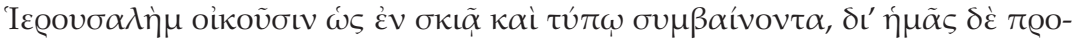

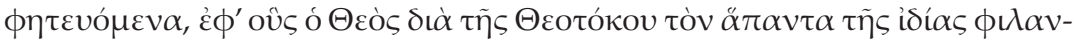

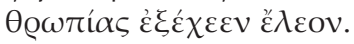

(22) I. e., the victory over the Nestorian heresy, consult PeltomaA, The Image..., esp. 85-101.

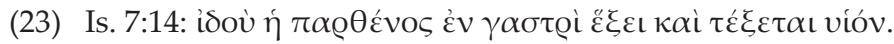

(24) Proclus of Constantinople as a Marian Preacher, see PeltomaA, The Image..., 101-113, esp. 103. 
result of the protection of God as follows: "From the seedles womb he came, / preserving it chaste as it was before, / so that, beholding the miracle, we might sing her praise, crying...". ${ }^{25}$

Although the influence of the Akathistos does not reveal itself as direct citations in the homily, its introduction is in full harmony with the text of the Akathistos. In other words, the point of departure of Syncellus is certainly identical with the Akathistos. The Akathistos celebrates the mystery of the Incarnation of God the Word which takes place through the Virgin for the redemption of humankind out of the philantrophy of God. The homilist constructs an analogue: the recent rescue of the Constantinopolitans from death is a miracle which, on account of the philanthropy of God, became possible through the Virgin from whom God the Word became incarnated.

What follows next is a report "on the great things that the Lord of powers has done through the Theotokos." ${ }^{26}$ Among many other historical facts, the audience is informed that the "mighty" emperor, Heraclius, before leaving for the Persian front, "entrusted the throne to his son, the imperial prince." ${ }^{27}$ At the same time the city was entrusted to the guardianship of God and the Virgin. ${ }^{28}$ Inspite of an old peace treaty between the Avar king and the emperor, as soon as Heraclius was out of his way, Khagan, "this wild beast" ( $\theta \dot{\eta} \varrho)$ started the preparations for the assault upon the city. The enemies devised all kinds of tricks, "even manufactured engines, to make the town of God, protected by

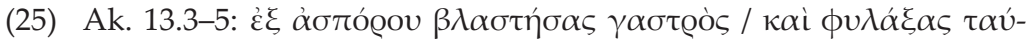

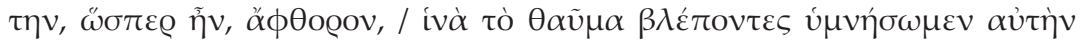

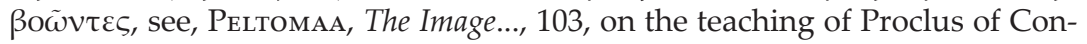
stantinople, 176.

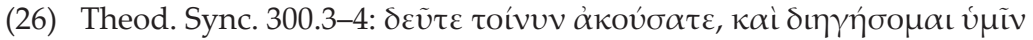

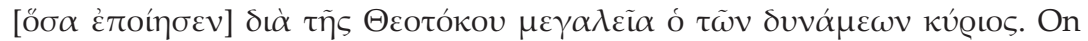
the lacuna, see S. SzÁDECZKY-KaRdoss, Eine unkollationierte Handschrift der Homilie über die persisch-awarische Belagerung von Konstantinopel (Codex Athous Batopedi 84, Fol. 63-68r), in: IDEM, AVARICA. Über die Awarengeschichte und ihre Quellen (Szeged, 1986) (Acta Antiqua et Archaeologica, 24) 187-195, here 88-89, "Bestätigung einer Konjunktur".

(27) Consult W. E. Kaegi, Heraclius. Emperor of Byzantium (Cambridge, 2003).

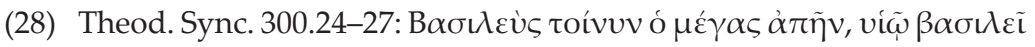

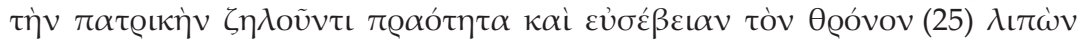

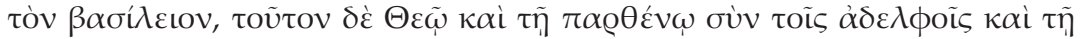

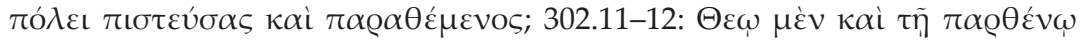

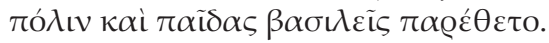


the Virgin, the booty of this deer." ${ }^{29}$ Here the expression "protected by the Virgin" demands attention, for the translation does not render the

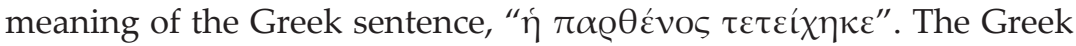
verb has the same root as the word $\tau \varepsilon \tilde{\chi} \chi 0 \varsigma$, a 'wall', especially a 'city-

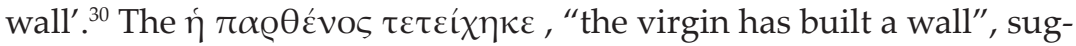
gests that the Virgin had erected another - spiritual - wall of the city. It is more than likely that Syncellus echoes the emphatical acclaim at the end of the Akathistos: "Hail, impregnable wall of the kingdom." The other passage, in which the word "wall" appears in the Akathistos, is associated with virginity: "For virgins and all who flee to you / you are a wall, O Virgin Theotokos," ${ }^{32}$ but also this idea is relevant in Syncellus, as we will see below.

According to Syncellus, having heard the news from the homefront, the emperor raised his hands towards the sky and cried: "You Lord, all-observing and knowing all, you know that I entrusted to you

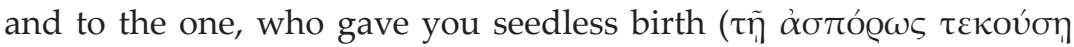
$\sigma \varepsilon)$, my children, the city and your people living their." ${ }^{33}$ Here may suffice to remark that the "seedless birth" is found in three passages in the Akathistos. The prayer of the emperor to God is finished with the following plea: "So keep now, according to your own law, safe and well, the city which I entrusted to the force of your power and the Theotokos, the mother of your goodness." 34

The account continues with the happenings in the city. The children of the emperor were praying in a small chapel of the Mother of God, attached to the palace. In the light of the Akathistos it is quite interesting what Syncellus puts into words in this context. So, the chil-

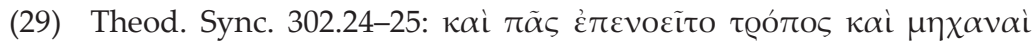

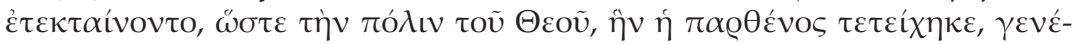

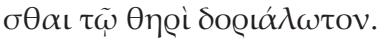

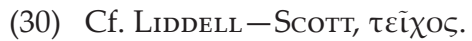

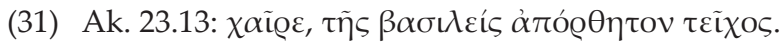

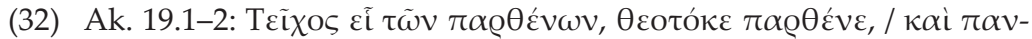

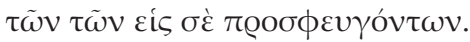

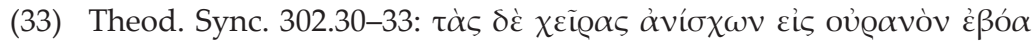

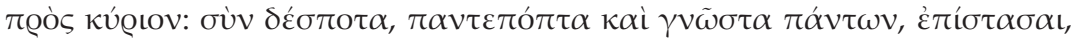

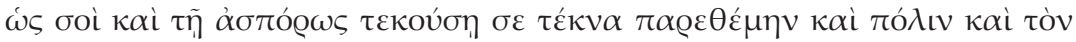

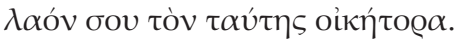

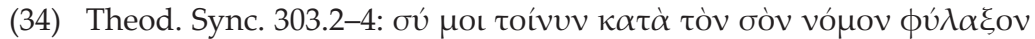

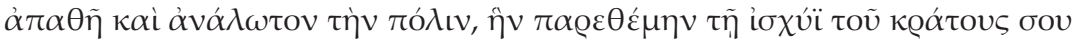

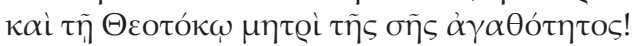


dren "offered their innocence of children and their heart, just as the virginity and the purity of their bodies, as an supplication and sweetsmelling incense." ${ }^{35}$ And they "exclaimed all in tears: "All-Powerful Lady! our father entrusted to you your city and us, your servants who are still children, as you see it, All-Holy, and he had given us to

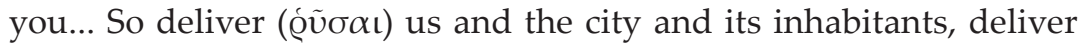

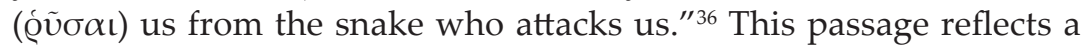
strong influence from the Akathistos. Picturing to himself the imperial children, the author presents both the ideal of virginity and the thought of virginity as an offering. This is precisely that kind of ascetic idealism that the Akathistos advocates. ${ }^{37}$ Besides, virginity as an offering to the Theotokos is explicit in the last strophe: "O Mother hymned by all, / you who gave birth to the Word, the holiest of all

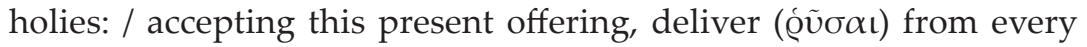
evil..." ${ }^{38}$ It is conspicious that Syncellus uses in this context the word @ṽ $\sigma \alpha \iota$ twice. ${ }^{39}$ On the whole, the Akathistos seems to have been in the author's mind.

Sergius, the patriarch of Constantinople, was the main actor of the siege drama in the view of Theodore Syncellus. ${ }^{40}$ Sergius the "wor-

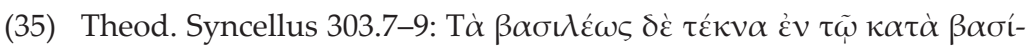

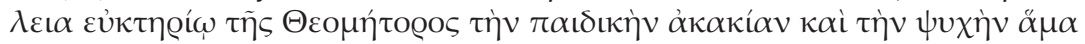

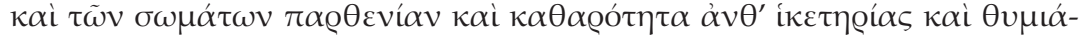

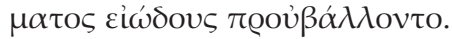

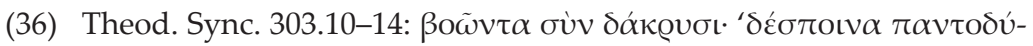

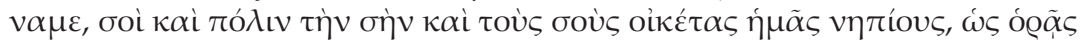

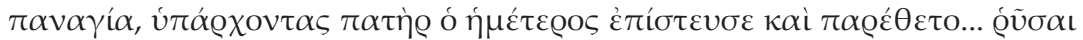

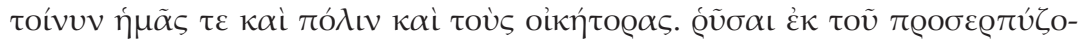

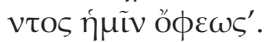

(37) On the ihe ideal of virginity, esp. strophes 17, 18, 19, see PeltomaA, The Image..., 185-199.

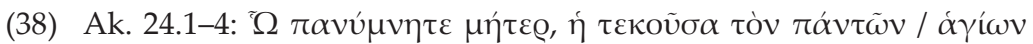

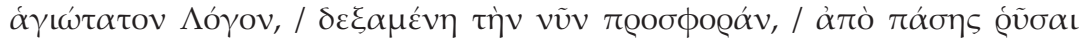

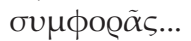

(39) The verb is found elsewhere only once, Theod. Sync. 307.3-38: $\delta \varepsilon \sigma-$

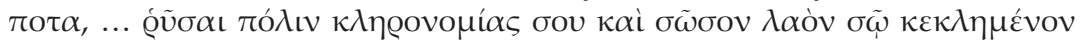

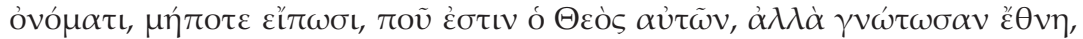

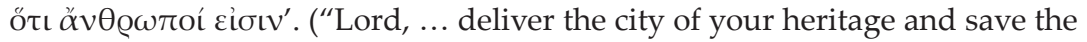
people who are called by your name, so that they would newer say, 'Where is their God?', but let those people ( $\left.\varepsilon^{\prime} \theta v \eta\right)$ know that the are only human!")

(40) So also in the eyes of George of Pisidia, but the Chronicon Paschale is silent about Sergius. The view of modern scholarship is presented by, e.g. 
thy archpriest, our Isaiah", ${ }^{41}$ gathered everyone, if he were a priest or clerk, living as a monk or among the people, of the men of any age, from the child to the old man. He harangued them to be brave and not discouraged: "The enemy attacks us on horse and with war engines, with an enormous multitude, but we will overcome by the holy name of our Lord God. Because the Lord himself fights for us, and because

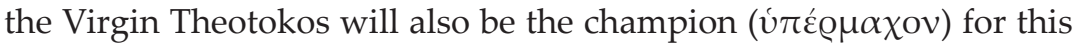
city, if we ourselves turn all our heart toward them with all out hear and a devoted soul." ${ }^{42}$ In this same context we find also the following assertion of Syncellus: "The fact that they raised their hands to God

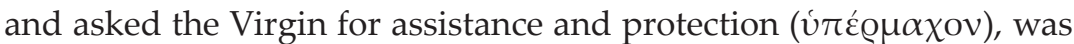
a weapon, sabre and shield for all the inhabitants of the city." ${ }^{33}$ The

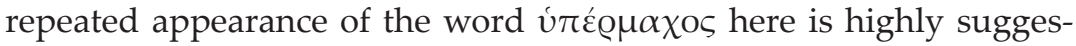
tive - as if Mary's role as the defender or protector of Constantinople had been established already before the siege. This may have been the case. Anyhow, the epithet $v \pi \varepsilon \dot{Q} \mu \alpha \chi 0 \varsigma$ for saints seems to have become popular in hagiography during the sixth century, ${ }^{44}$ although as a Marian epithet it is actually known from the Akathistos' prooemium

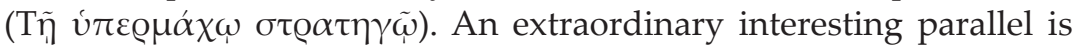
found in the Life of Saint Theodosius, composed by Cyril of Scythopolis (ob. c. 558), saying: "Theodosius, worthily called blessed and citizen of heaven, the great glory of Palestine and boast of the desert, the

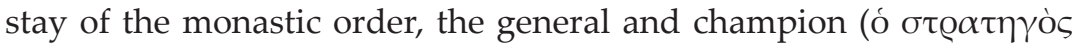

van Dieten, Geschichte der Patriarchen..., 12-19. “Den Höhepunkt der politischen Tätigkeit Sergios' bildet ohne Zweifel die and erster Stelle (d.h. nach Gott und der Theotokos) ihm zugeschriebene Rettung der Stadt aus der Avarenbelagerung" (p. 12).

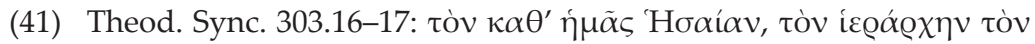
тíutov.

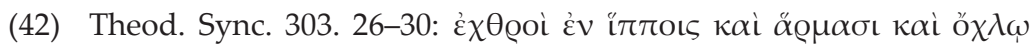

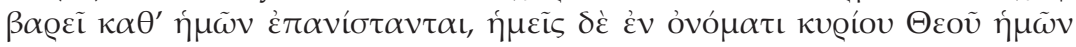

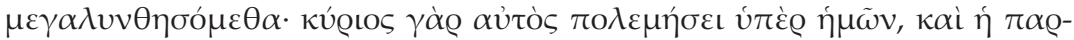
Ө

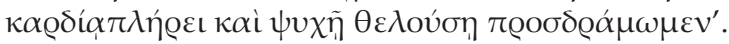

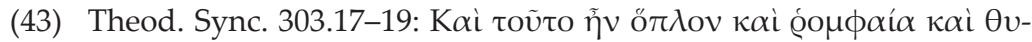

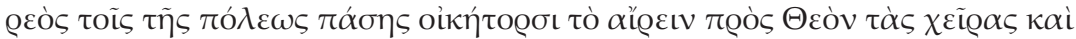

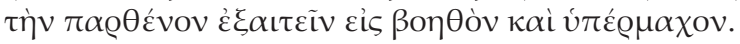

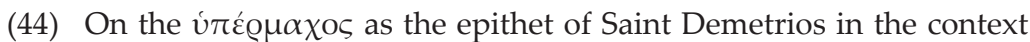
of the siege of Thessalonike, J. Koder, Anmerkungen zu den Miracula Santi Demetrii, in: BYZANTIUM. Tribute to Andreas N. Stratos, vol. 2 (Athens, 1986) 523-538, esp. 527-528. 


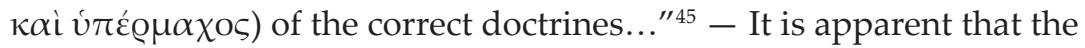
whole section of the homily (Theod. Sync. 303.7-32), dedicated to the prayers of the imperial children and the patriarch is deep and full of resonance of the Akathistos.

The story about Sergius continues. He used icons in defence. This passage of icons includes an intellectual link to the Akathistos, embedded in the story of Sergius' actions. Therefore it is best to quote the relevant lines of the Akathistos at first, for this is not the only place where Syncellus alludes the Theotokos, having this image in mind: "Shining upon Egypt the light of truth / you dispelled the darkness of falsehood, / for her idols, O Saviour, / fell down unable to endure your power, / and those who were saved from them cried to the Theotokos: / ... Hail, downfall of demons / ... Hail, sea that drowned the spiritual Pharaoh." 46 Following Syncellus, the icons were hung at all the western doors of the city. They pictured the Virgin, "carrying in her arms the Lord, to whom she had given birth". These icons were "like the most brilliant sun, driving out the darkness by its rays" (Ak. "Shining upon Egypt the light of truth / you dispelled the darkness of falsehood"). Then Sergius shouted to the masses of barbarians and the demons leading them (Ak. "Hail, downfall of demons"): "Oh foreign people and diabolical hordes, you have undertaken the whole war against these. But the woman Theotokos will put an end to all your boldness and pride by its only call, because she is really the mother of the One who drowned Pharaoh and all his army in the middle of the Red Sea (Ak. "Hail, sea that drowned the spiritual Pharaoh"), and discouraged and weakened all the diabolical horde." ${ }^{\prime 7}$ The idea that

(45) TLG from E. Schwartz, Kyrillos von Sykthopolis (Leipzig, 1939)

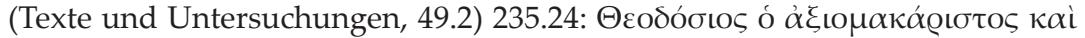

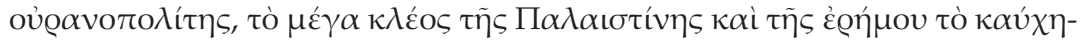

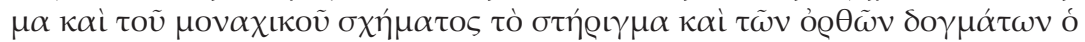

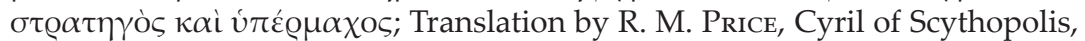
The Lives of the Monks of Palestine (Kalamazoo, Michigan, 1991) 262.

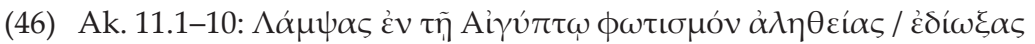

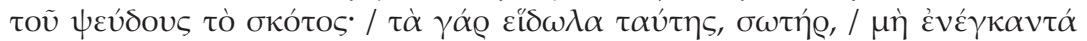

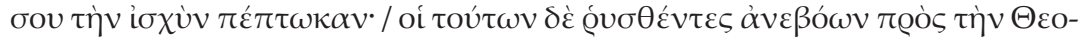

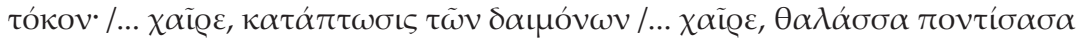

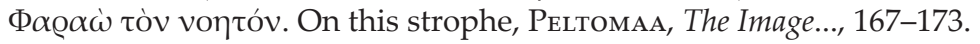

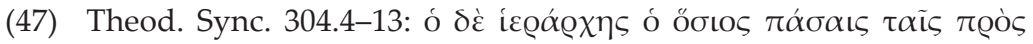

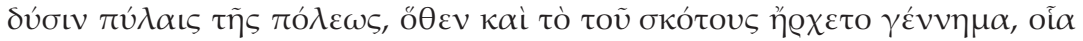

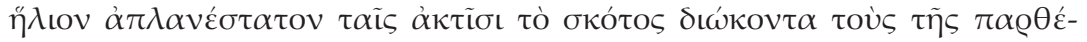

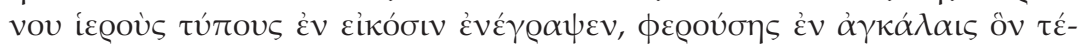


Pharaoh was drowned (in the final end) through the Theotokos (since she is the mother) is the striking common feature between the Akathistos and the homily. Likewise, in both of them, the contrast between the powers of darkness and the power of the Sun is pointed out. According to the Byzantines' Christian understanding of the order of the world, it is all about the Incarnation, understood as liberation, prefigured by the crossing of the Red Sea by Israelis and realized through Mary. This theme is of greatest symbolic importance to Syncellus, because he refers to it altogether four times. ${ }^{48}$

At this stage we can state that there are in the homily no further examples that as clearly as those presented above would demonstrate that the Akathistos is reflected in Syncellus' text. This fact is to be regarded as the main piece of evidence for dating the prooemium to the

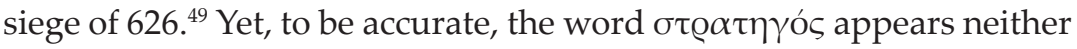
in the homily nor in the twenty four strophes of the Akathistos. Nev-

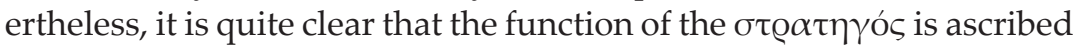
to Mary by Syncellus, e.g. in his report on the fight at the church of the Pege (Theod. Sync. 305.37-306.12): “The Virgin was present everywhere, overcame without being overcome, spread fear and horror on the enemy, while giving strength to her servants. She preserved her subjects safe and sound, and devastated the enemy masses." 50

The strategy the Theotokos used in the decisive sea battle is described in detail (Theod. Sync. 311.17-40). Syncellus, maintaining that the Theotokos made the monoxyla with their men sink, assures that the Virgin herself won the fight and this victory: "Those who fought

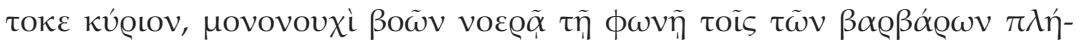

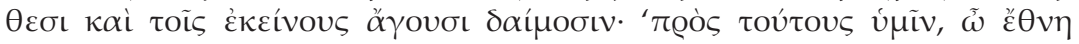

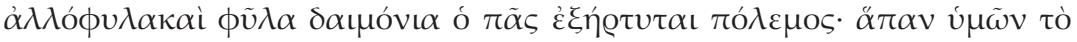

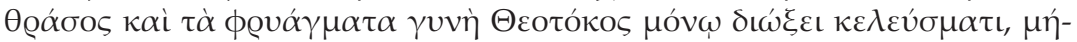

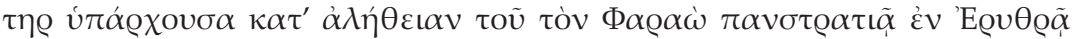

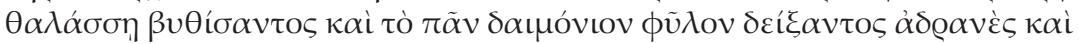

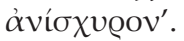

(48) Theod. Sync. 308.10-15; 311.17-40; 317.40-318.8.

(49) Contra Sреск, Zufälliges zum Bellum avaricum..., 140: „Das spricht weder für noch gegen die Annahme, dass 626 aus Dank der Akathistos Hymnos gesungen wurde... da wir zwar in einer Predigt am ehesten eine soche Anspielung erwarten dürften, Theod. Synk. sich aber auf die Bibel beschränkt."

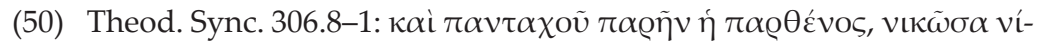

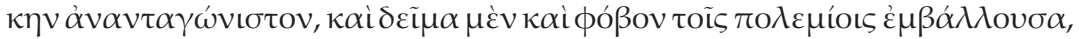

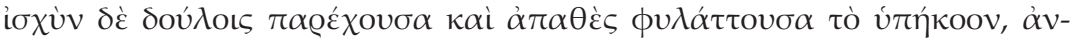

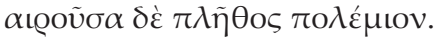


on the sea, on our vessels, turn around at the first attack of the enemy force and they failed to beat a retreat, and by that they would have made almost possible attacks by the enemy, if the pity ( $\phi\llcorner\lambda \alpha \dot{v} \theta \varrho \omega \pi \mathrm{ov})$ of the Virgin had not prevented this misfortune, refusing to endure such a spectacle. She put in action her own force and power. Not like Moses, dividing and uniting again the floods of the Red Sea by his staff, but only by her gesture and her pure will she made the chariots of Pharaoh and his army to sink... Some say that ours were not withdrawn from the fear of the enemy, but that it is the Virgin herself who wanted to demonstrate the oikonomia of the miracle. In consequence of that, the barbarians sank completely, in front of her holy church, in the bridge of our rescue, our easily accessible ( $\varepsilon \dot{v} \delta\llcorner\mathrm{v}$ ) harbour, because all that was the church of the Mother of God in Blachernae." ${ }^{51}$

The siege was the extreme experience of a crisis to the Constantinopolitans. ${ }^{52}$ There is no doubt that they were praying days and nights, without rest ( $\alpha \kappa \alpha \tau \alpha \tau \alpha u ́ \sigma \tau o v) .{ }^{53}$ "The enemy tribes thus encircled the city on the East and on the West, by sea and on the North. But the city begged in tears the Virgin by the words of the inspired mouth of the archpriest: 'Save me, oh Lady, save me, because I will perish. Do not remain dumb, inactive, silent any longer, because I know that you are powerful'." ${ }^{54}$ When the siege was over, and they were delivered, they

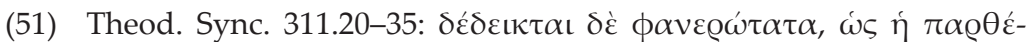

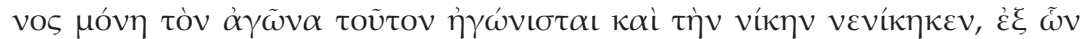

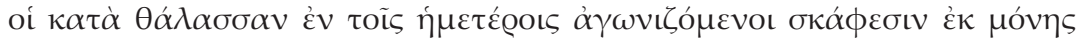

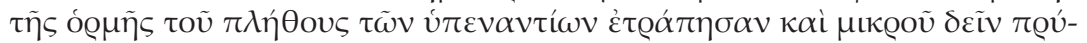

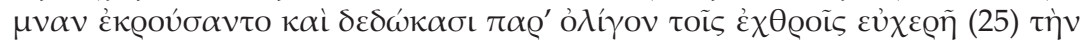

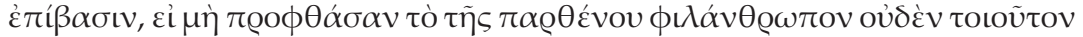

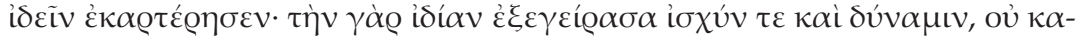

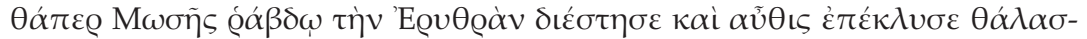

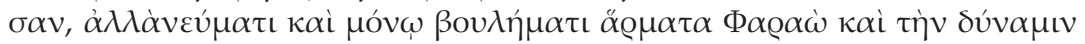

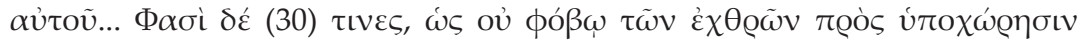

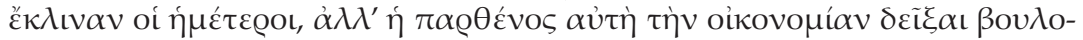

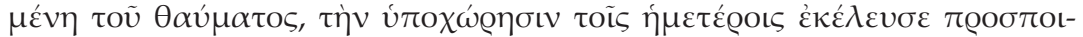

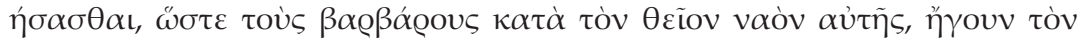

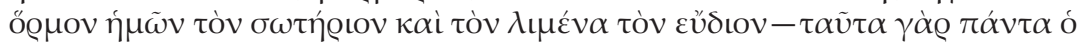

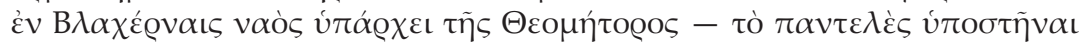
vaváłiov.

(52) E.g., Theod. Sync. 304.27-30.

(53) Theod. Sync. 303.30.

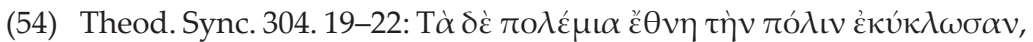

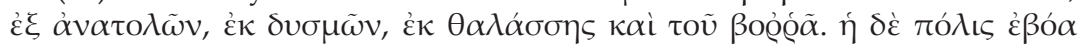


sang, praised and glorified the Lord as the church of God.$^{55}$ They ran to Blachernae, which Syncellus calls the holy house of the Mother of God, the "invincible guard of the city and its inhabitants." ${ }^{56}$ In such context Theodore Syncellus puts the question: "But now, that the Lord saved us of all these dangers, what thanksgiving do we owe, in exchange for what they did for us, to the Lord and the Virgin Mother of God? What praise and what glorification should we sing for the benefits in which we have taken part? ${ }^{57}$ Syncellus makes only a rhetorical question, because people, his audience, knew what they had sung. To us an answer is transmitted by the manuscript tradition which connects the Akathistos Hymn and the following prooemium: ${ }^{58}$

To you, our leader in battle and defender,

O Theotokos, I, your city, delivered from sufferings, ascribe hymns of victory and thanksgiving.

Since you are invincible in power, free me from all kind of dangers, that I may cry to you:

"Hail, bride unwedded." 59

There is no doubt that the contents of these lines, the refrain included, corresponds both to the narrative of Syncellus and its ethos. It is clear that the refrain comes from the Akathistos Hymn, in which it is repeated twelve times. "The refrain 'Hail, bride unwedded', with which the series of salutations to Mary conclude, leaves its stamp on

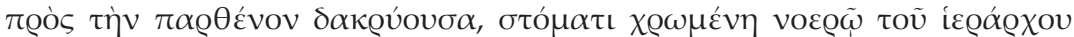

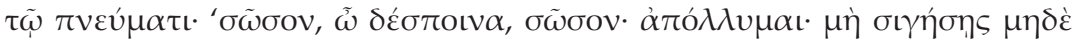

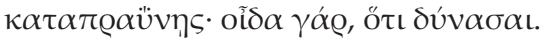

(55) Theod. Sync. 318.21-39.

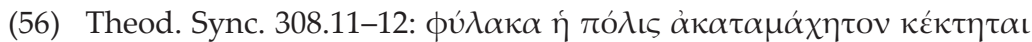

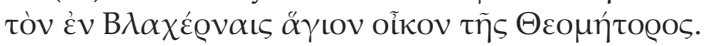

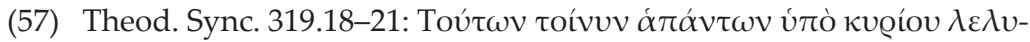

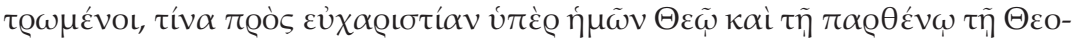

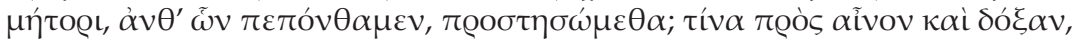

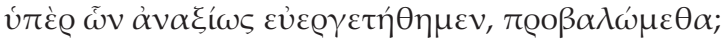

(58) Consult Trypanis, Fourteen Early Byzantine Cantica..., 9-21 with bibliography.

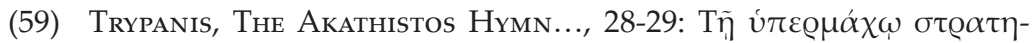

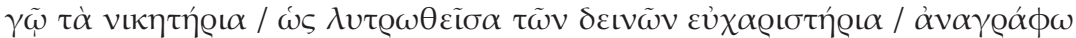

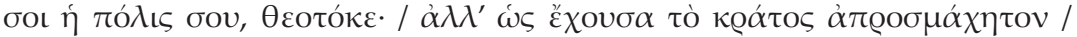

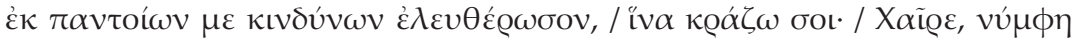

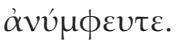


whe whole hymn, as well as on the image of Mary." ${ }^{60}$ It can be added that the image of Mary in Syncellus' homily, too, represents that one of the Virgin. The word $\pi \alpha \varrho \theta \varepsilon$ c $o \varsigma$ appears 43 times, whereas the Theotokos only 17 times. (In the Akathistos the ratio is 70 to 34.)

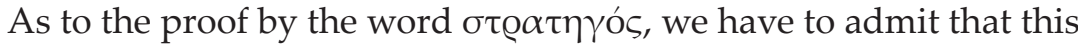
evidence alone is not sufficient for claiming that the Tĩ $v \pi \varepsilon Q \mu \alpha \alpha \chi \omega$ $\sigma \tau \varrho \alpha \tau \eta \gamma \tilde{\omega}$ dates back to the siege of 626. Fortunately, the poem of George of Pisidia, On the Attack of the Barbars and Their Failure, ${ }^{61}$ supplies us with the missing link. This work was composed probably rather soon after the siege, presenting, in principle, the same account as the homily of Syncellus. It is striking that George of Pisidia calls the The-

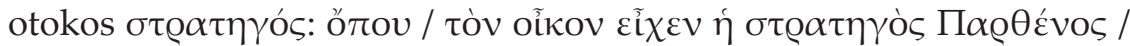
where the General Virgin had her house (444-445). Further, he addresses acclamations to Sergius, the patriarch, whom he gives credit for the defence of the capital:

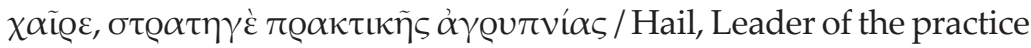
of vigilance (137),

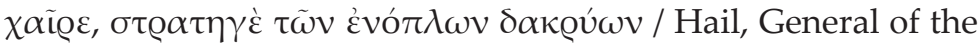
tears of the armed (141).

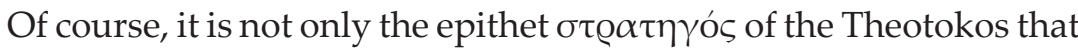
attracts our attention here but the word $\chi \alpha \tilde{\mathrm{i}} \varepsilon \varepsilon$, the very characteristic of the Akathistos Hymn. ${ }^{62}$ The overlapping and partly identical imagery used by George for his leading figures, the Theotokos and Sergius, makes it here difficult to determine which of them he addresses, ${ }^{63}$ but the model of the Akathistos cannot be overlooked. Thus the question,

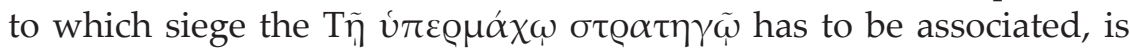
answered to, but at the same time a new intriguing question arises for further research: Could the author of the prooemium of the Akathistos be George of Pisidia?

(60) PeltomaA, The Image..., 205.

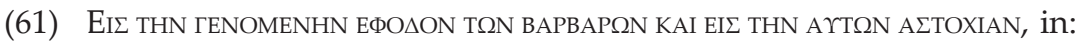
L. Tartaglia (ed.), Carmi di Georgio di Pisidia (Torino, 1998) (Classici Greci collezione. Autori della tarda antichità e dell'età bizantina) 156-191.

(62) I thank cordially Wolfram Hörandner, Vienna, for his reading and commenting the texts of Theodore Syncellus and George of Pisidia.

(63) This is a difficulty which Mary Whitby carefully discusses in her paper on George of Pisidia, Defenders of the Cross: George of Pisidia on the Emperor Heraclius and His Debuties, included in: M. Whiтвy (ed.), The Propaganda of Power. The Role of Panegyric in Late Antiquity (Leiden-Boston-Brill, 1998) (Mnemosyne) 247-273, consult esp. 266-267. 


\section{SUMMARY}

The paper concerns dating the prooemium of the Akathistos Hymn,

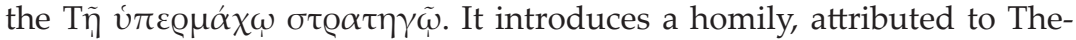
odore Syncellus, as an evidence of the mutual relationship between the siege of Constantinople in 626 and the Akathistos Hymn and its prooemium. $\Delta$ ogmatical, ideological and linguistic parallels demonstrate that the Akathistos is reflected in Syncellus' text. Further it is shown that in

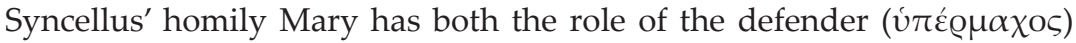

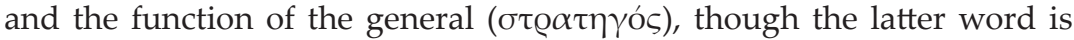
not employed explicitely. As a contemporary text, the poem by George of Pisidia on the siege of 626, includes the word $\sigma \tau \varrho \alpha \tau \eta \gamma$ ó $\varsigma$, even together with the word $\chi \alpha \tilde{i} \mathrm{\rho} \varepsilon$, the very characteristic of the Akathistos, it provides

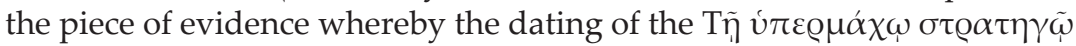
to the first siege of Constantinope is justified. 